\title{
Dysmorphism-pectus carinatum-joint laxity syndrome
}

INSERM

\section{Source}

INSERM. (1999). Orphanet: an online rare disease and orphan drug data base.

Dysmorphism-pectus carinatum-joint laxity syndrome. ORPHA:2104

Dysmorphism-pectus carinatum-joint laxity syndrome is characterised by joint laxity,

pectus carinatum and facial dysmorphism (mild frontal bossing, a beaked nose with a low nasal bridge, malar hypoplasia, chubby cheeks, a striking philtrum and arched upper lips).

It has been described in two siblings. The mode of transmission is unknown. 